\title{
Hubungan Kebiasaan Minum Teh Terhadap Kejadian Gout Athritis Pada Warga Jamaah Masjid Al Manshuurin Yabansai, Waena Jayapura
}

\author{
HERLAMBANG B. MULYONO, TRAJANUS L. JEMBISE \\ Fakultas Kedokteran Universitas Cenderawasih, Jayapura, Papua \\ Diterima: 06 Agustus 2018 - Disetujui: 16 September 2018 \\ (C) 2018 Jurusan Biologi FMIPA Universitas Cenderawasih
}

\begin{abstract}
Tea is a common drink that consumed in Indonesia. Caffein is one of the ingredients of tea. coffee has been shown to increase urinary excretion which is also likely to increase uric acid excretion. Gout is a disease cause of high level of uric acid in blood stream. The aim of this study was to determine the tea drinkers influences serum uric acid level in the residents of Al Manshuurin Mosque Yabansai Waena Jayapura. We enrolled 45 participants in this cross sectional study. An assessment of various dietary intake amounts of substances such as tea was performed using a food frequency questionnaire. The content of tea (15 mg/cup) intake information from the past year. Descriptive and Chi square analysis were applied to identify any association of dietary intake with serum uric acid levels or the risk of gout arthritis. The results showed that the tea drinkers had a lower risk than the not tea drinkers ( $p=0.01$ respectively). The conclusion of this study is tea drinkers have lower uric acid levels in blood.
\end{abstract}

Key words: Gout, Tea drinkers, uric acid.

\section{PENDAHULUAN}

Produk minuman yang paling populer dan banyak diminati masyarakat Indonesia maupun dunia adalah teh. Preferensi masyarakat yang tinggi terhadap minuman teh disebabkan oleh berbagai alasan. Salah satunya adalah teh diyakini mengandung banyak khasiat, aroma dan rasa yang khas serta tradisi tertentu. Khasiat dalam kesehatan teh dapat mencegah kanker, kegemukan, dan bahaya kolesterol. Seiring perkembangan teknologi yang semakain canggih terkait pengolahan teh saat ini maka banyak dijumpai produk teh kemasan seperti teh celup, teh kering, teh dalam botol sehingga mudah dikonsumsi. Berdasarkan proses pengolahannya,

* Alamat korespondensi:

Fakultas Kedokteran, Universitas Cenderawasih, Jayapura, Papua. Jl. Raya Abepura, Jayapura, Papua. 99351. E-mail: herlambangbm@yahoo.com teh diklasifikasikan ke dalam tiga jenis yaitu teh fermentasi (teh hitam), teh semi fermentasi (teh olong) dan teh tanpa fermentasi (teh hijau) (Hartoyo, 2003).

Kandungan teh secara umum adalah kafein, tanin, dan minyak esensial. Unsur kafein memberikan rasa segar dan mendorong kerja jantung manusia, tidak berbahaya jika dikonsumsi tidak melebihi $300 \mathrm{mg} /$ hari. Unsur tanin adalah sumber energi yang berasal dari sari teh tersebut. Sedangkan minyak esensial memberikan rasa dan bau harum yang merupakan faktor-faktor pokok dalam menentukan nilai dalam setiap cangkir teh yang dijual atau diperdagangkan (Soemantri, 2011).

Penggunaan teh hijau lebih dari $300 \mathrm{mg} /$ hari (sekitar 5 cangkir teh hijau) dapat mengakibatkan efek samping, misalnya gelisah, insomnia atau sulit tidur, diare, mudah tersinggung, sakit kepala, dan hilangnya nafsu makan. Jika berinteraksi dengan obat sintetik, teh hijau dapat mem- 
perlambat penyerapan obat ke dalam tubuh (Jatuworapruk et al., 2014). Kandungan tanin dalam teh dapat digunakan sebagai pedoman mutu, karena tanin memberikan cita rasa yang khas terhadap teh tersebut yaitu rasa yang sedikit sepat (Soemantri, 2011).

Asam urat adalah produk akhir dari metabolisme purin yang dapat mengendap dalam jaringan dan bisa menyebabkan peradangan yang dikenal dengan gout. Gout merupakan salah satu penyakit metabolik yang terjadi akibat tingginya kadar asam urat dalam darah. Kadar asam urat sangat erat kaitannya dengan pola hidup yang dijalani, pola konsumsi makanan yang salah, serta penyalahgunaan alkohol yang terjadi di masyarakat secara meluas (Plaoze \& Steward, 2012).

Jumlah penderita asam urat cenderung meningkat dari waktu ke waktu. Berdasarkan data dari Rumah Sakit Umum Nasional Dr. Cipto Mangunkusumo (RSCM) menunjukkan terjadi kenaikan penderita sekitar 9 orang dari tahun 1993 sampai 1994 dan sekitar 19 orang dari 1994 sampai 1995. Pada tahun 2007, menurut data responden yang berobat di klinik RSCM Jakarta, penderita asam urat sekitar $7 \%$ dari keseluruhan responden yang menderita penyakit rematik (Abdi, 2014). Kelebihan asam urat dalam darah ini menjadi masalah yang cukup serius, terutama bagi orang yang berusia 40 tahun ke atas. Kadar asam urat darah yang berlebihan bisa menyebabkan timbulnya suatu penyakit yang disebut dengan artritis gout. Penyakit ini memang tidak mematikan, namun menyebabkan nyeri luar biasa serta menurunkan kualitas hidup (Arthur, 2014).

Salah satu kandungan di dalam teh adalah kafein. Dalam penelitian terdahulu menunjukkan bahwa kandungan kafein yang terdapat dalam kopi dan dapat mempengaruhi kadar asam urat dalam darah (Petrie et al., 2004). Peran kafein terbukti dapat meningkatkan ekskresi urine, sedangkan ekskresi asam urat sebagian besar di urin. Sehingga jumlah asam urat dalam darah diharapkan akan menurun. Kafeein memiliki efekterhadap kesehatan publik, maka dengan mengetahui konsumsi kafeein dan dampaknya terhadap kadar asam urat maka diharapkan masyarakat bijak dalam konsumsi kafeein demi kesehatan mereka (Martinez et al., 2004). Kelompok jamaah yang berada di lingkungan masjid Al Manshuurin Yabansai, Waena memiliki tradisi yang sudah lama untuk meminum teh setiap pengajian. Hal ini sudah berlangsung lama dan bertahun-tahun. Agenda pengajian kelompok jamaah tiga kali dalam seminggu dan selalu tersedia minuman teh, dan kebiasaan ini terbawa dalam lingkungan rumah hampir setiap hari warga jamaah minum teh. Pada kondisi demikian maka potensi menderita gout akan terbuka luas sehingga peneliti tertarik untuk melakukan kajian tentang kejadian gout dan kebiasaan meminum teh pada warga jamaah masjid Al Manshuurin Yabansai.

\section{METODE PENELITIAN}

\section{Waktu dan Tempat}

Penelitian dilakukan di kompleks Masjid Al Manshuurin Yabansai Waena Jayapura mulai Juli sampai September 2018.

\section{Metode Pelaksanaan}

Desain penelitian ini adalah analitik cross sectional. Sampel penelitian berasal dari 47 orang responden. Dengan kriteria inklusi adalah tinggal di kompleks masjid paling sedikit dua tahun terhitung 2018, usia diatas 40 tahun, dan bersedia ikut penelitian. Pengumpulan data diperoleh dari data primer. Data primer diperoleh langsung dari subyek penelitian menggunakan kuesioner dan hasil pemeriksaan laboratorium. Pemeriksaan laboratorium dilakukan dengan metode dengan metode stik. Metode stik menggunakan alat UASure Blood Uric Meter. Alat tersebut memiliki prinsip menggunakan katalis yang dikombinasi dengan teknologi biosensor khusus pada pengukuran asam urat.

\section{Pengolahan dan Analisis Data.}

Analisis data penelitian menggunakan pendekatan chi square dan statistik deskriptif digunakan untuk mengetahui gambaran umum responden yang positif menderita gout serta akan 
ditampilkan dalam distribusi dan kecenderungan pola data menggunakan program SPSS V 17.

\section{HASIL DAN PEMBAHASAN}

\section{Karakteritik responden}

Penelitian ini melibatkan 47 responden yang terbagi menjadi 27 orang laki laki atau 57,4 dan 20 orang wanita atau $42,6 \%$. Seluruh responden merupakan warga kompleks Masjid Al Manshuurin Yabansai Waena yang bermukim lebih dari tiga tahun dan aktif mengikuti kajian di Masjid tersebut. Mayoritas responden berasal dari Jawa Tengah dan Jawa Timur serta beberapa dari Sulawesi Selatan dan Buton. Data distribusi responden berdasarkan jenis kelamin (Tabel 1).

Responden yang terlibat dalam penelitian ini memiliki berbagai pekerjaan masing-masing sesuai dengan dengan jenis kelamin (Tabel 1). Jumlah total responden laki-laki ada 27 orang yang tersebar menjadi 7 orang bekerja sebagai PNS, 16 orang menekuni pekerjaan swasta dan sisanya 4 orang dalam kategori pekerjaan lainnya. Sedangkan jumlah total wanita ada 20 orang yang terbagi menjadi 4 orang bekerja sebagai PNS, 6 orang berwiraswasta dan 10 orang bekerja lainnya. Seluruh sampel antara wanita dan laki laki yang bekerja sebagai PNS ada 11 orang, swasta terdapat 22 orang dan lainnya 14 orang.

Sampel penelitian yang menderita asam urat tinggi dan tergolong peminum teh tedapat 6 orang, sedangkan status asam urat normal tapi peminum teh sebanyak 16 orang sehingga total responden yang tergolong peminum teh sebanyak 22 orang. Di sisi lain responden yang tidak termasuk non peminum teh tetapi memiliki stats asam urat tinggi sebesar 19 orang, dan status asam urat normal hanya ada 6 orang saja sehingga total non pemimum teh sebanyak 25 orang. Data sebaran antara status asam urat dan kebiasaan minum teh (Tabel 3).

Dasar pengambilan keputusan uji chi square adalah melihat hasil perhitungan signifikansi (2sided) pada taraf 0,05. Dasar keputusan tersebut adalah jika nilai signifikansi lebih kecil dari 0,05 maka terdapat hubungan antara baris dan kolom sedangkan jika nilai signifikansi lebih besar maka tidak terdapat hubungan yang signifikan antara baris dan kolom (Tabel 2). Pada hasil perhitungan di atas tampak bahwa nilai sig 0,001 yang berarti terdapat hubungan yang signifikan antara kebiasaan meminum teh dan status asam urat bagi warga jamaah Masjid Al Manshuurin Yabansai Waena Jayapura.

\section{Pembahasan}

Peningkatan kadar asam urat dalam darah menimbulkan penyakit degeneratif yang dikenal dengan penyakit gout. Nilai batas kejenuhan asam urat dalam serum darah pada laki laki 7,0 mg/dl

Tabel 1. Distribusi responden berdasarkan jenis kelamin.

\begin{tabular}{cccccc}
\hline & & Frequency & Percent & Valid Percent & Cumulative Percent \\
\hline \multirow{2}{*}{ Valid } & laki - laki & 27 & 57,4 & 57,4 & 57,4 \\
& wanita & 20 & 42,6 & 42,6 & 100,0 \\
& Total & 47 & 100,0 & 100,0 & \\
\hline
\end{tabular}

Tabel 2. Crostabulasi antara jenis kelamin dan jenis pekerjaan responden.

\begin{tabular}{rlccc}
\hline & & \multicolumn{2}{c}{ jenis kelamin } & \multirow{2}{*}{ Total } \\
\cline { 3 - 4 } & & laki - laki & wanita & \\
\hline \multirow{2}{*}{ Pekeraan responden } & PNS & 7 & 4 & 11 \\
& Swasta & 16 & 6 & 22 \\
& Lainnya & 4 & 10 & 14 \\
\hline Total & & 27 & 20 & 47 \\
\hline
\end{tabular}


Tabel 3. Cros tabulasi antara kebiasaan meminum teh dan status asam urat.

\begin{tabular}{clccc}
\hline & & \multicolumn{2}{c}{ Status asam urat } & \\
\cline { 2 - 3 } & & Tinggi & Normal & Total \\
\hline Kebiasaan minum teh & Peminum teh & 6 & 16 & 22 \\
& Non peminum teh & 19 & 6 & 25 \\
\hline & Total & 25 & 22 & 47 \\
\hline
\end{tabular}

Tabel 4. Hasil uji chi square responden pemimun tah dan status asam urat.

\begin{tabular}{|c|c|c|c|c|c|}
\hline & Value & $d f$ & Asymp. Sig. (2-sided) & Exact Sig. (2-sided) & Exact Sig. (1-sided) \\
\hline Pearson Chi-Square & $11,159^{a}$ & 1 & ,001 & \multirow{7}{*}{,001 } & \multirow{7}{*}{,001 } \\
\hline Continuity Correction ${ }^{b}$ & 9,288 & 1 & ,002 & & \\
\hline Likelihood Ratio & 11,628 & 1 & ,001 & & \\
\hline Fisher's Exact Test & & & & & \\
\hline Linear-by-Linear & 10,922 & 1 & ,001 & & \\
\hline $\begin{array}{l}\text { Association } \\
N \text { of Valid Cases }\end{array}$ & & & & & \\
\hline$N$ of Valid Cases & 47 & & & & \\
\hline
\end{tabular}

dan pada perempuan 5,7 $\mathrm{mg} / \mathrm{dl}$. Jumlah asam urat yang melebihi batas normal dalam darah pada seseorang dinamakan dengan hiperurisemia.

Pada penelitian ini menunjukkan bahwa responden yang memiliki kadar asam urat dalam darah yang tinggi adalah 25 orang, dimana 6 orang tergolong peminum teh, dan 19 orang tergolong non peminum teh. Sebanyak 22 responden memiliki kadar asam urat dalam darah yang normal, dimana yang tergolong peminum teh sebanyak 16 orang dan yang non peminum teh sebanyak 6 orang. Persentase responden yang memiliki kadar asam urat dalam darah tinggi

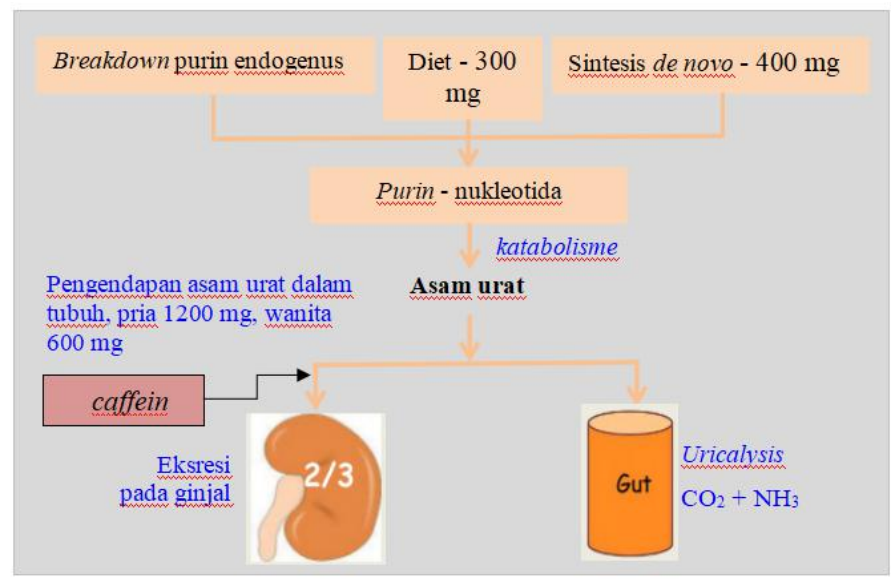

Gambar 1. Sumber dan eksresi asam urat yang melibatkan senyawa cafein dan organ ginjal. pada golongan peminum teh $24 \%$ sedangkan pada golongan non peminum teh yang memiliki kadar asam urat dalam darah tinggi sebanyak $72,7 \%$. Hasil menunjukkan bahwa teh mampu menurunkan kadar asam urat dalam darah. Sesuai dengan hipotesis bahwa kandungan caffein dalam teh meningkatkan jumlah ekskresi asam urat di urine. Pada akhirnya akan menurunkan kadar asam urat dalam darah.

Sumber purin di dalam tubuh berasal dari tiga jalur. Pertama purin diperoleh dari luar tubuh berupa diet optimal yang berasal dari berbagai minuman atau makanan yang mengandung purin sebanyak $300 \mathrm{mg}$. Kedua sumber purin yang diperoleh dari dalam tubuh dengan cara memecah jenis purin endogen (Mertinez et al., 2004; Soemantri, 2011). Kemudian yang terakhir kebutuhan purin yang berasal dari dalam tubuh juga namun bersifat de novo atau sintesa hasil purin yang diperoleh dari molekul-molekul sederhana. Hasil input ketiga sumber purin/de novo tersebut akan menghasilkan purin nukleotida. Metabolit ini pada gilirannya akan mengalami katabolisme berupa asam urat. Asam urat hasil katabolisme akan diekskresi melewati ginjal dan usus. Besaran nilai asam urat yang diekskresi melalui usus sebanyak $1 / 3$ bagian, di sini asam urat akan mengalami urikolisis yang 
diubah menjadi dua metabolit berupa $\mathrm{CO}_{2}$ dan $\mathrm{NH}_{3}$. Sedangkan jumlah asam urat yang melalui ginjal sebanyak 2/3 bagian, akan diekskresikan bersama urin. Kandungan cafein dalam teh secara klinis terbukti meningkatkan produksi ekskresi urine dengan cara peningkatan Glomerulus Filtration Rate (GFR). Tingginya ekskresi urine menyebabkan ekskresi metabolit-metabolit darah yang lain pun akan naik, termasuk di dalamnya adalah asam urat. Sehingga hasil penelitian ini menunjukkan pengaruh yang signifikan dari kebiasaan minum teh terhadap rendahnya kadar asam urat dalam darah dengan nilai sig: 0,01. Sejalan dengan penelitian Nugraheni et al. (2017) yang menunjukkan pengaruh teh hijau dalam menurunkan kadar asam urat dalam darah dan meningkatkan kadar asam urat dalam urine pada tikus putih. Demikian juga pada penelitian (Bahoruna et al., 2009) yang mendapatkan hasil bahwa minum teh hitam lebih dari 3 gelas perhari mampu menurunkan kadar asam urat dan $\mathrm{C}$ reaktif protein dalam darah.

Penelitian ini berbeda dengan penelitian Zang et al. (2017) menyatakan hasil studi kohort menunjukkan bahwa tidak terdapat hubungan anatar kebiasaan minum teh dan risiko terkena gout pada laki laki dan perempuan. Perbedaan pengolahan daun teh akan mempengaruhi tingkat oksidasi dari poliphenol dari daun teh. Namun demikian hasil penelitian ini juga tidak berbeda dengan temuan lain yang menyatakan bahwa kadar asam urat dalam darah tidak memiliki hubungan yang signifikan dengan peningkatan minum kopi, namun tidak dengan asupan minium teh. Faktor lain yang berhubungan dengan kadar asam urat dalam temuan tersebut juga dipengaruhi oleh faktor resiko hiperuresemia, usia, jenis kelamin, index massa tubuh, fungsu ginja, penggunaan alkohol, hipertensi dan penggunaan bahan diuretik (Choi \& Curhan, 2007).

Penelitian ini menggunakan sampel yang relatif kecil yakni kelompok Jamaah Masjid Al Manshuurin Yabansai Waena, sehingga hasil yang diperoleh belum maksimal sebagai hasil yang dapat mewakili kelompok lainnya. Selain itu, faktor perancu sebaiknya dikendalikan seperti kebiasaan konsumsi karbohidrat, makanan dan obat-obat tertentu yang mempunyai efek terhadap metabolisme purin. Penelitian ini diharapkan menjadi titik awal untuk penelitian lain yang hasilnya dapat digunakan atau digeneralisasikan untuk populasi yang lebih luas.

\section{KESIMPULAN}

Penelitian ini menunjukkan adanya hubungan yang signifikan $(p=0.001)$ antara kebiasaan meminum teh dan status asam urat bagi warga jamaah Masjid Al Manshuurin Yabansai Waena Jayapura.

\section{DAFTAR PUSTAKA}

Abdi, W. 2014. Prevalensi penderita reumatic pada Panti Jompo Kenanga Intan Depok periode 2011-2015. Jurnal Orthopaedi. 43(1): 5-39.

Arthur, W. 2014. Green tea consumption and decreased risk of recurrent gout attacks. Arthritis Rheum Journal. 32(3): 44-51.

Bahoruna, T., A. Luximon-Ramma, T.K. Gunness, Sookar, S. Bhoyroo, R. Jugessur, D. Reebye, K. Googoolyea, A. Crozier, and O.I. Aruoma. 2009. Black tea reduces uric acid and C-reactive protein levels in humans susceptible to cardiovascular diseases. Journal Toxicology. 278: 68-74.

Choi, H.K., and G. Curhan. 2007. Coffee, tea, and caffeine consumption and serum uric acid level: The third national health and nutrition examination survey, athritis \& rheumatism. Arthritis Care E Research. 57(5): 816-821.

Hartoyo, A. 2003. Teh dan khasiatnya bagi kesehatan: Sebuah tinjauan ilmiah. Penerbit Kanisius. Yogyakarta.

Jatuworapruk, K., S. Srichairatanakool, S. Ounjaijean, N. Kasitanon, S. Wangkaew, and W. Louthrenoo. 2014. Effects of green tea extract on serum uric acid and urate clearance in healthy individuals. Journal of Clinical Rheumatology. 20(6): 310-314.

Martinez, S., A.A. Willett, L.M.F. Manson, and M.J. Stampfer. 2004. Coffee consumption and risk for type 2 diabetes mellitus. Ann Intern Med. 140: 1-8.

Nugraheni, P.W., F. Rahmawati, C. Mahdi and S. Prasetyawan. 2017. Green tea extract (Camellia sinensis L.) effects on uric acid levels on hyperuricemia rats (Rattus norvegicus). J Pure App. Chem. Res. 6(3): 246-254.

Petrie, H.J., S.E. Chown, LM. Belfie, A.M. Duncan, D.H. McLaren, and J.A. Conquer 2004. Caffeine ingestion increases the insulin response to an oral-glucosetolerance test in obese men before and after weight loss. Am J Clin Nutr. 80: 22-28.

Plaoze, O., and P. Steward. 2012. Basic biochemical of green tea. Biochem Med Journal. 34(11): 355-363. 
Soemantri, R. 2011. Kisah dan khasiat teh. Penerbit PT. Gramedia Pustaka Utama. Jakarta.

Zhang, Y.Z., Cui, X. Li, L.-J. Li, X. Xie, Y.-Z. Huang, Y.-H. Deng, C. Zeng and G.-H. Lei. 2017. Is tea consumption associated with the serum uric acid level, hyperuricemia or the risk of gout? A systematic review and metaanalysis. BMC Musculoskeletal Disorders. 3(18): 95. 